\title{
Effects of cadmium on survival and morphology of cultured rat Sertoli cells
}

\author{
T. Espevik*, M. K. Lamvik $\dagger$, A. Sunde* and Kristen B. Eik-Nes \\ Institute of Biophysics, University of Trondheim, $N$-7034 Trondheim-NTH, Norway
}

\begin{abstract}
Summary. The toxicity of different metals on isolated Sertoli cells grown in culture has been investigated. Methyl mercury $\left(\mathrm{CH}_{3} \mathrm{HgCl}\right)$ and mercury chloride $\left(\mathrm{HgCl}_{2}\right)$ were more toxic than cadmium $\left(\mathrm{CdCl}_{2}\right)$ which was slightly more toxic than arsenic $\left(\mathrm{As}_{2} \mathrm{O}_{3}\right)$. Isolated peritubular cells and Sertoli cells were equally sensitive to cadmium. Cadmium reduced the Sertoli cell survival over the concentration range of 1-10 $\mu \mathrm{M}$. Freeze-etch electron microscopy of cadmium-exposed Sertoli cells revealed circular areas of average diameter $500 \mathrm{~nm}$ devoid of intramembrane particles in the nuclear membrane, and general signs of degeneration such as vesiculation of the plasma membrane and intramembrane particle aggregation. However, cadmium did not dissolve junctional complexes between Sertoli cells. Isolated Sertoli cells were protected against cadmium-induced damage when the cells were preincubated for $48 \mathrm{~h}$ with selenium, zinc or low doses of cadmium. Preincubation with cobalt, FSH, testosterone or oestradiol did not protect against cadmium-induced damage. Cadmium bound to metallothionein had no toxic effects on isolated Sertoli cells.
\end{abstract}

\section{Introduction}

Parizek (1957) reported that cadmium salts have damaging effects on mammalian testes. The early injurious effects of this metal on the male gonad are on the vascular system (Meek, 1959; Kar \& Das, 1960; Mason, Brown, Young \& Nesbit, 1964; Chiquoine, 1964; Gunn \& Gould, 1975; Aoki \& Hoffer, 1978) and further cadmium-induced changes may be secondary to ischaemia (Aoki \& Hoffer, 1978). Saksena \& Lau (1979) demonstrated that testes from rats treated subcutaneously with $5 \mathrm{mg}$ cadmium chloride $\left(\mathrm{CdCl}_{2}\right)$ regained steroidogenic capacity but the animals remained sterile for 120 days after treatment. Such information indicates that cadmium causes permanent damage of the germinal components of the testes.

Germ cells are closely associated with Sertoli cells (Fawcett, 1975). Since no information exists on the effects of cadmium on isolated Sertoli cells, we tested the survival of cadmium-exposed Sertoli cells and used freeze-etch electron microscopy to investigate how cadmium alters the morphology of isolated Sertoli cells grown in culture.

It has been demonstrated that agents like selenium can protect the vascular endothelium of the rat testis against cadmium damage (Niewenhuis \& Fende, 1978). Protection against testicular damage due to cadmium appears to be mediated by metallothionein in mice (Nordberg, 1971). FSH, testosterone and oestradiol are known to interfere with Sertoli cell function in vivo (Verjans, de Jong, Cooke, van der Molen \& Eik-Nes, 1972; Ahmad, Haltmeyer \& Eik-Nes,

\footnotetext{
* Present address: The Institute of Cancer Research in Trondheim, University of Trondheim, N-7000 Trondheim, Norway.

$\uparrow$ Present address: Fritz-Haber-Institut, Faradayweg 4-6, D-1000 Berlin 33, West Germany.
} 
1973) and in vitro (Dorrington, Roller \& Fritz, 1975; Fritz, Rommerts, Louis \& Dorrington, 1976; Rommerts, Krüger-Sewnarain, Van Woerkom-Blik, Grootegoed \& van der Molen, 1978). Because of the expected biological activities of these agents it was considered important to investigate whether they interacted with the effect of cadmium on isolated Sertoli cells grown in culture.

\section{Sertoli cells}

\section{Materials and Methods}

Preparation. Testes with a mean weight of $65 \mathrm{mg}$ were obtained from 20-day-old Wistar rats. Sertoli cell-enriched aggregates were prepared by the method of Fritz et al. (1976) except for the following modification: during preparation of cell aggregates, the tubular fragments were suspended in Eagle's minimum essential medium with Hepes buffer (Gibco) instead of Hank's balanced salt solution.

Culture conditions. The culture medium consisted of Eagle's minimum essential medium, supplemented with non-essential amino acids, L-glutamine, penicillin/streptomycin $(100 \mu \mathrm{g} / \mathrm{ml}$ each) and fungizone $(0.63 \mu \mathrm{g} / \mathrm{ml})$. To prevent the possible effects of unknown serum factors, blood serum was not added to the medium. Aliquots of the suspension containing Sertoli cell-enriched aggregates were plated either on Thermanox plastic slides placed in Costar Petri dishes or in Falcon plastic bottles. About 2 bottles were obtained per testis. After addition of $5 \mathrm{ml}$ culture medium the cultures were incubated in a water-saturated atmosphere of $95 \%$ air and $5 \%$ $\mathrm{CO}_{2}$ at $32^{\circ} \mathrm{C}$. The culture medium was changed after $48 \mathrm{~h}$.

\section{Peritubular cell preparation and culture}

Peritubular cells were isolated as described by Rommerts et al. (1978). The isolated peritubular cells were cultured in the medium described above but supplemented with $1 \%$ chicken serum (Gibco). The peritubular cells were allowed to grow for 1 week before transfer to new culture flasks and growth for 1 additional week. During these 2 weeks of the experiment, the culture medium was changed every $48 \mathrm{~h}$. For 2 days before the addition of cadmium chloride and during exposure to this metal the cells were grown in a serum-free medium.

\section{Sertoli and peritubular cell survival}

Sertoli cells were grown in culture for $48 \mathrm{~h}$ before $\mathrm{CdCl}_{2}, \mathrm{HgCl}_{2}, \mathrm{CH}_{3} \mathrm{HgCl}, \mathrm{As}_{2} \mathrm{O}_{3}$, $\mathrm{NiSO}_{4} \cdot 6 \mathrm{H}_{2} \mathrm{O}, \mathrm{Mn}\left(\mathrm{NO}_{3}\right)_{2} 4 \mathrm{H}_{2} \mathrm{O}, \mathrm{Pb}\left(\mathrm{NO}_{3}\right)_{2}, \mathrm{ZnCl}_{2}, \mathrm{CoCl}_{2}, \mathrm{Na}_{2} \mathrm{SeO}_{3}$ or metallothionein were added to the incubation medium. All metals were obtained from Merck, except for $\mathrm{CH}_{3} \mathrm{HgCl}$ which was a gift from Dr Tore Syversen, Institute of Pharmacology and Toxicology, University of Trondheim, Norway. Metallothionein of known purity (Nordberg, 1971) was kindly donated by Dr Monica Nordberg, Department of Environmental Hygiene, the Karolinska Institute, Stockholm, Sweden. Before the metals were added, $100-400$ cells were selected and photographed with a Leitz inverted phase-contrast microscope. Further samples of cells were photographed and counted 24,48 and $72 \mathrm{~h}$ after addition of the metals. Cell viability was estimated by the method of Rotman \& Papermaster (1966), using fluorescein diacetate (Koch-Light Laboratories Ltd).

In some experiments Sertoli cell cultures were incubated with FSH (NIH-oFSH-S9), oestradiol (Steraloids Inc.) or testosterone (Steraloids).

\section{Freeze-etch electron microscopy}

Sertoli cells were cultured on Thermanox plastic cover-slips. After the appropriate culture period the cover-slips were quickly cut into $3 \times 3 \mathrm{~mm}$ squares and the Sertoli cells frozen in situ 
with a liquid propane jet-freezer according to Espevik \& Elgsaeter (1981). The frozen specimens were fractured, etched for $1 \mathrm{~min}$ at $-100^{\circ} \mathrm{C}$, and replicated using a freeze-etch unit described by Elgsaeter (1978). The replicas were examined in a JEOL 100B or $100 \mathrm{CX}$ electron microscope. The terminology of Branton et al. (1975) is used for designating the fracture faces. The shadows in the freeze-etch electron micrographs are white.

\section{Results}

\section{Effects of different metals on Sertoli cell survival}

Among the compounds tested only methyl mercury $\left(\mathrm{CH}_{3} \mathrm{HgCl}\right)$ and mercury chloride $\left(\mathrm{HgCl}_{2}\right)$ were more toxic for the Sertoli cells than cadmium chloride $\left(\mathrm{CdCl}_{2}\right)$. Arsenic $\left(\mathrm{As}_{2} \mathrm{O}_{3}\right)$ was slightly less toxic (Text-fig. 1). Sertoli cell survival decreased during exposure to $\mathrm{CdCl}_{2}$ over the concentration range of $1-10 \mu \mathrm{M}$. For $\mathrm{CH}_{3} \mathrm{HgCl}$ such effects were seen between 0.44 and $0.89 \mu \mathrm{M}$, for $\mathrm{HgCl}_{2}$ between 0.44 and $8.9 \mu \mathrm{M}$, and for $\mathrm{As}_{2} \mathrm{O}_{3}$ between 4.45 and $17.8 \mu \mathrm{M}$ (Text-fig. 1). At a fixed concentration of $8.9 \mu \mathrm{M}-\mathrm{ZnCl}_{2}, \mathrm{CoCl}_{2}, \mathrm{Na}_{2} \mathrm{SeO}_{3}, \mathrm{NiSO}_{4} 6 \mathrm{H}_{2} \mathrm{O}, \mathrm{Mn}\left(\mathrm{NO}_{3}\right)_{2} 4 \mathrm{H}_{2} \mathrm{O}$ or $\mathrm{Pb}\left(\mathrm{NO}_{3}\right)_{2}$ no such effect on Sertoli cell survival could be detected after $72 \mathrm{~h}$ of exposure. Cadmium bound to metallothionein equivalent to a dose of $26.7 \mu \mathrm{M}$ cadium and $19.8 \mu \mathrm{M}$ zinc had no effect on Sertoli cell survival after $72 \mathrm{~h}$. If $26.7 \mu \mathrm{M}-\mathrm{CdCl}_{2}$ and $19.8 \mu \mathrm{M} \mathrm{ZnCl} \mathrm{Zn}_{2}$ were added simultaneously to cultures, the cell survival was reduced to about $5 \%$ after $72 \mathrm{~h}$.

To test whether cultured Sertoli cells were particularly sensitive towards $\mathrm{CdCl}_{2}$, isolated testicular peritubular cells were cultured and exposed to $\mathrm{CdCl}_{2}$ under the same conditions as Sertoli cells. No significant difference was found between peritubular cell and Sertoli cell survival when $\mathrm{CdCl}_{2}$ was added to cultures (data not shown).

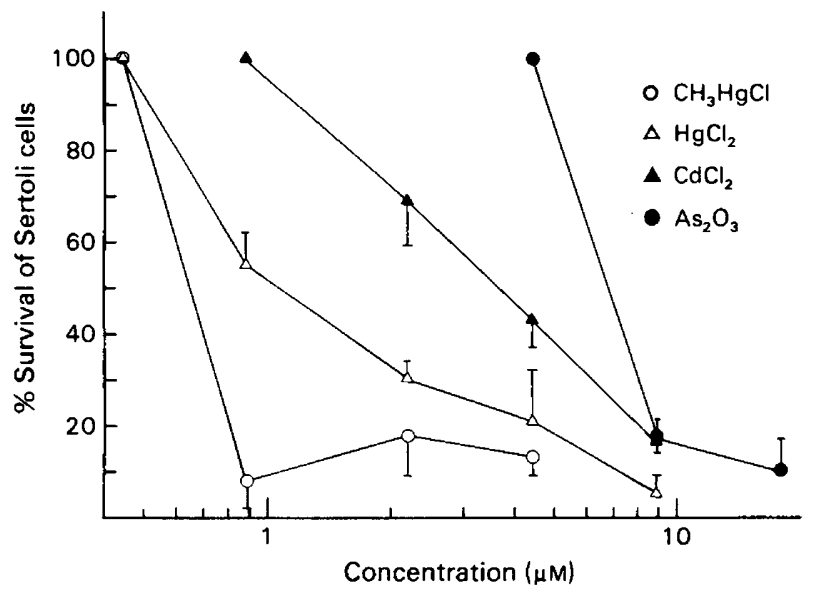

Text-fig. 1. Effects of different metals on Sertoli cell survival over $72 \mathrm{~h}$. Results are mean values \pm s.e. of two determinations in duplicate cultures.

\section{Protection against $\mathrm{CdCl}_{2}$-induced Sertoli cell damage}

Cultures of Sertoli cells were preincubated with the test substance for $48 \mathrm{~h}$. The medium was then changed and fresh medium containing $8.9 \mu \mathrm{M} \mathrm{CdCl}_{2}$ was added to the cultures. Sertoli cell survival was recorded 24,48 and $72 \mathrm{~h}$ after the latter addition.

This assay revealed that preincubation with $8.9 \mu \mathrm{M}-\mathrm{Na}_{2} \mathrm{SeO}_{3}$ protected the Sertoli cells in the first $24 \mathrm{~h}$ after exposure to $\mathrm{CdCl}_{2}$. This protection effect was not present at $72 \mathrm{~h}$ (Text-fig. 2a). 
Preincubation with $2 \cdot 2 \mu \mathrm{M}-\mathrm{CdCl}_{2}$ significantly protected the Sertoli cells over the whole $72 \mathrm{~h}$ period but had maximum effect after $24 \mathrm{~h}$ (Text-fig. 2b). The dose of $2.2 \mu \mathrm{M}-\mathrm{CdCl}_{2}$ per se reduced Sertoli cell survival to $73 \pm 4 \%$ after $48 \mathrm{~h}$ of preincubation. Sertoli cells preincubated with $17.8 \mu \mathrm{M}-\mathrm{ZnCl}_{2}$ displayed significantly increased cell survival 24,48 and $72 \mathrm{~h}$ after addition of $\mathrm{CdCl}_{2}$ but this dose of $17.8 \mu \mathrm{M}-\mathrm{ZnCl}_{2}$ did not by itself affect Sertoli cell survival over $48 \mathrm{~h}$.

We were not able to demonstrate protection against the standard dose of $8.9 \mu \mathrm{M}-\mathrm{CdCl}_{2}$ when the cells were preincubated with $8.9 \mu \mathrm{M}-\mathrm{CoCl}_{2}, 5 \mu \mathrm{M}-\mathrm{FSH}, 0.1 \mu \mathrm{M}$-testosterone or 0.1 $\mu \mathrm{M}$-oestradiol.
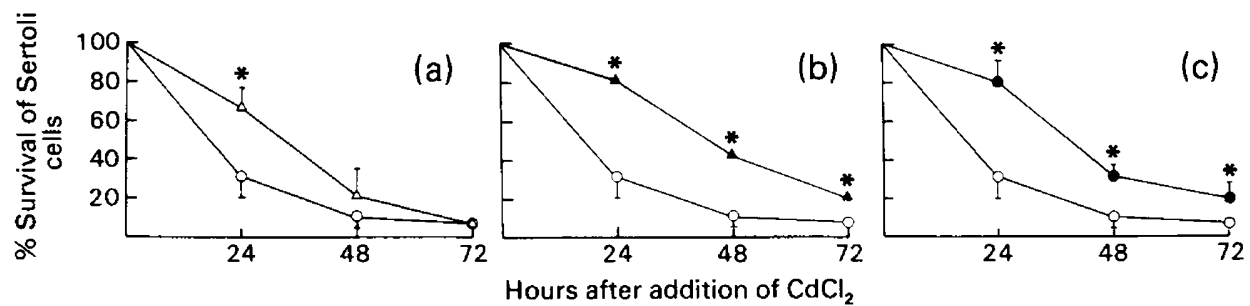

Text-fig. 2. Sertoli cell survival as function of time after a $8.9 \mu \mathrm{M}-\mathrm{CdCl}_{2}$ dose was added to cultures (O). (a) Pretreatment with $8.9 \mu \mathrm{M}-\mathrm{Na}_{2} \mathrm{SeO}_{3}$ for $48 \mathrm{~h}$ before addition of $\mathrm{CdCl}_{2}(\triangle)$. (b) Pretreatment with $2.2 \mu \mathrm{M}-\mathrm{CdCl}_{2}$ for $48 \mathrm{~h}$ before addition of $\mathrm{CdCl}_{2}$ (A). (c) Pretreatment with $17.8 \mu \mathrm{M}-\mathrm{ZnCl}_{2}$ for $48 \mathrm{~h}$ before addition of $\mathrm{CdCl}_{2}(\bullet)$. Results are mean values \pm s.e. of two determinations in duplicate cultures. Where the s.e. is not indicated it is within the symbol. ${ }^{*} P<$ 0.025 (Student's $t$ test).

\section{Alterations of Sertoli cell morphology after $\mathrm{CdCl}_{2}$ treatment}

Freeze-etch electron microscopy of $\mathrm{CdCl}_{2}$-exposed Sertoli cells often revealed well defined circular areas in the nuclear membrane devoid of intramembrane particles (Pl. 1, Fig. 1). These circular areas had a uniform size, about $500 \mathrm{~nm}$. Such features in the nuclear membrane were not observed in control Sertoli cells or in cells exposed to 17.8 or $8.9 \mu \mathrm{M}-\mathrm{ZnCl}_{2}$. Sertoli cells subjected to $\mathrm{CdCl}_{2}$ exhibited various degrees of intramembrane particle aggregation in the plasma membrane (Pl. 1, Fig. 2) although the pattern was different from that in the nuclear membrane. Vesiculation of the plasma membrane was a frequent occurrence and many vesicles were observed in the surrounding growth medium (P1. 1, Fig. 2). In spite of these apparent signs of degeneration junctional complexes (mainly tight junctions) were still prominent between the Sertoli cells (Pl. 1, Fig. 2).

\section{Discussion}

It is difficult to study the specific effects of cadmium on testes in vivo because such studies involve problems of distinguishing between cadmium-induced injury and injury secondary to ischaemia (Aoki \& Hoffer, 1978). Sertoli cells cultured under certain conditions maintain many of their

\section{PLATE 1}

Fig. 1. Freeze-etch electron micrograph of a nuclear membrane from a propane jet-frozen Sertoli cell exposed to $8.9 \mu \mathrm{M}-\mathrm{CdCl}_{2}$ for $24 \mathrm{~h}$, showing a circular area in the nuclear membrane devoid of intramembrane particles. Nuclear pores in the membrane are visible.

Fig. 2. Freeze-etch electron micrograph of plasma membranes from propane jet-frozen Sertoli cells exposed to $8.9 \mu \mathrm{M}-\mathrm{CdCl}_{2}$ for $24 \mathrm{~h}$. Junctional complexes, mainly tight junctions (arrows) are still intact. Notice vesiculation of the plasma membrane (arrow heads) and aggregation of intramembrane particles on the protoplasmic fracture face (PF). EF, extracellular fracture face. 


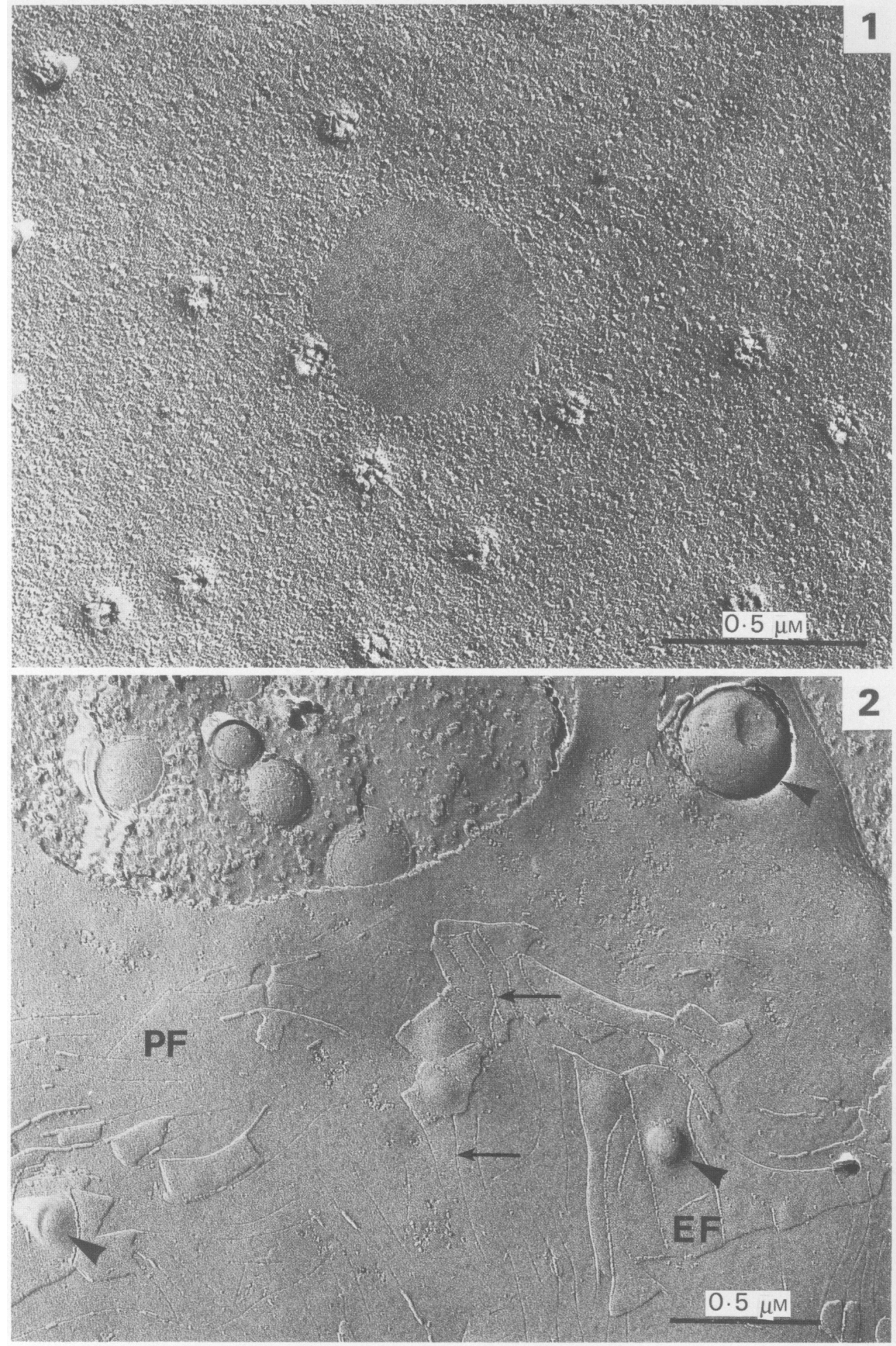

(Facing p. 492) 
physiological properties (Dorrington et al., 1975; Fritz et al., 1976; Gore-Langton, McKeracher \& Dorrington, 1980; Elkington \& Fritz, 1980; Kiergzenbaum et al., 1980). In the present study we have cultured Sertoli cells under these conditions to examine the toxicity of metals on the cells. Only $\mathrm{CH}_{3} \mathrm{HgCl}$ and $\mathrm{HgCl}_{2}$ were more toxic for the Sertoli cells than $\mathrm{CdCl}_{2}$.

The $\mathrm{LD}_{50}$ for $\mathrm{CdCl}_{2}$-exposed rabbit alveolar macrophages in vitro is about $100 \mu \mathrm{M}$ (Waters, Gardner, Aranyi \& Coffin, 1975) and the $\mathrm{LD}_{50}$ for $\mathrm{CdCl}_{2}$-exposed NHIK 3025 cells in vitro is $30 \mu \mathrm{M}$ (unpublished results). These values are considerably higher than the $\operatorname{LD}_{50}(3.6 \mu \mathrm{M})$ for cultured Sertoli cells (Text-fig. 1). The different serum concentrations required for proper growth of macrophages and NHIK 3025 cells in vitro could account for these differences in LD $_{50}$ doses. Cultured Sertoli cells could, however, be particularly sensitive towards $\mathrm{CdCl}_{2}$. Peritubular cells were therefore isolated and cultured under the same conditions as Sertoli cells. No significant difference in cell survival following cadmium exposure was found between isolated Sertoli and peritubular cells. This fact may indicate that peritubular cells are also affected in acute testicular cadmium poisoning in vivo.

Sertoli cells pretreated with $\mathrm{Na}_{2} \mathrm{SeO}_{3}, \mathrm{ZnCl}_{2}$ or a low dose of $\mathrm{CdCl}_{2}$ were not as sensitive towards a standard high dose of $\mathrm{CdCl}_{2}$ as Sertoli cells not exposed to these pretreatments (Text-fig. 2), suggesting that isolated Sertoli cells are able to synthesize substances protecting them against cadmium-induced damages. Chen, Wagner, Hoekstra \& Ganther (1974) reported that pretreatment with $\mathrm{NaSeO}_{3}$, zinc acetate or low dose of $\mathrm{CdCl}_{3}$ resulted in different patterns of cadmium binding to proteins in rat testes. It is therefore possible that the testes are able to synthesize cadmium-binding proteins and that the Sertoli cells are possibly involved in this process. Cultured HeLa cells (Rudd \& Herschman, 1979), human fibroblasts (Lucis, Shaikh \& Embil, 1970) and epithelial cells (Rugstad \& Nordseth, 1975) have all been shown to produce metallothionein. However, metallothionein containing the equivalent of $26.7 \mu \mathrm{M}$-cadmium and $19.8 \mu \mathrm{M}$-zinc did not affect the survival of Sertoli cells over a $72 \mathrm{~h}$ period and cadmium bound to this substance was not able to reduce the Sertoli cell survival. Niewenhuis \& Fende (1978) reported that pretreatment with $\mathrm{Na}_{2} \mathrm{SeO}_{3}$ prevented the progressive time-related changes in endothelial cell junctions in testes following injection of $\mathrm{CdCl}_{2}$ to the animal. They suggested that this apparent inactivation of $\mathrm{CdCl}_{2}$ must take place in the blood or at the surface of the endothelial cells rather than in the testis itself. We have demonstrated that Sertoli cells pretreated with $\mathrm{Na}_{2} \mathrm{SeO}_{3}$ are protected against $\mathrm{CdCl}_{2}$-induced Sertoli cell damage in the first $24 \mathrm{~h}$ (Text-fig. 2a). This result therefore indicates that the Sertoli cells may be involved in the inactivation of cadmium after selenium pretreatment. The ability of the Sertoli cells to synthesize substances protecting them from cadmium injury (Text-fig. 2) seems not to be regulated by FSH, testosterone or oestradiol in the doses and regimens used in our study. FSH and testosterone are known to stimulate both protein and steroid synthesis in culture (Dorrington et al., 1975; Fritz et al., 1976; Rommerts et al., 1978).

Fende \& Niewenhuis (1977) reported that the primary ultrastructural effects of $\mathrm{CdCl}_{2}$ on cryptorchid and scrotal testes of rats consisted of changes in the endothelial cell junctions of intratesticular capillaries. Niewenhuis \& Fende (1978) suggested that an interaction between cadmium and calcium could be responsible for the breakdown of the cell junctions between endothelial cells. Our freeze-etch electron microscopic study of $\mathrm{CdCl}_{2}$-exposed Sertoli cells demonstrated that the junctional complexes between Sertoli cells were hardly affected by $\mathrm{CdCl}_{2}$ (Pl. 1, Fig. 2). Nevertheless, the micrographs suggest that $\mathrm{CdCl}_{2}$ interferes with the nucleus. Bell, Masters, Ingram, Waters \& Shelburne (1979) documented the localization of cadmium in nuclear inclusions in cultured rabbit alveolar macrophages, observing lamellar substructures with an average diameter of $500 \mathrm{~nm}$ in the nucleus of frozen-sectioned macrophages. We observed circular areas devoid of intramembrane particles in the nuclear membrane of about the same diameter in the $\mathrm{CdCl}_{2}$-exposed Sertoli cells. Such features were never observed in $\mathrm{ZnCl}_{2}$-exposed or in control Sertoli cells and are therefore not likely to be an effect of cooling the cells before freezing (Wunderlich, Wallach, Speth \& Fisher, 1974). 
In conclusion, isolated Sertoli cells can be protected against cadmium toxicity by exogenous substances, and our results suggest that they also have the ability to produce endogenous protective substances but in the absence of such substances they are very sensitive to the effects of cadmium, undergoing extensive alterations during the source of exposure.

We thank the Institute of Botany, University of Trondheim, and Section of Electron Microscopy, Trondheim Regional Hospital, for use of their electron microscopes; K. Jacobsen for the work on $\mathrm{CdCl}_{2}$ effects on NHIK 3025 cell survival; Professor J. Lamvik for his generous help; and Mrs R. Grasdalen for technical assistance. T.E. is a research fellow of the Norwegian Society for Fighting Cancer, and M.K.L. is a research fellow of The Royal Norwegian Council for Scientific and Industrial Research.

\section{References}

Ahmad, N., Haltmeyer, G.C. \& Eik-Nes, K.B. (1973) Maintenance of spermatogenesis in rats with intratesticular implants containing testosterone or dihydrotestosterone. Biol. Reprod. 8, 411-419.

Aoki, A. \& Hoffer, A.P. (1978) Reexamination of the lesions in rat testis caused by cadmium. Biol. Reprod. 18, 579-591.

Bell, S.W., Masters, S.K., Ingram, P., Waters, M. \& Shelburne, J.D. (1979) Ultrastructure and x-ray microanalysis of macrophages exposed to cadmium chloride. In Scanning Electron Microscopy/1979/III, pp. 111-121. SEM Inc., AMF O'Hare, IL 60666, U.S.A.

Branton, D., Bullivant, S., Gilula, N.B., Karnovsky, M.I., Moor, H., Mühlethaler, K., Northcote, D.H., Pacher, L., Satir, B., Satir, P., Speth, Y., Staehlin, L.A., Steere, R.I. \& Weinstein, R.S. (1975) Freeze-etching nomenclature. Science, N.Y. 190, 54-56.

Chen, R.W., Wagner, P.A., Hoekstra, W.G. \& Ganther, H.E. (1974) Affinity labelling studies with ${ }^{109}$ cadmium in cadmium-induced testicular injury in rats. J. Reprod. Fert. 38, 239-306.

Chiquoine, A.D. (1964) Observations on the early events of cadmium necrosis of the testis. Anat. Rec. 149 , 23-36.

Dorrington, J.H., Roller, N.F. \& Fritz, I.B. (1975) Effects of follicle-stimulating hormone on cultures of Sertoli cell preparations. Molec. cell. Endocr. 3, 57-70.

Elgsaeter, A. (1978) A new freeze-etch unit for freezeetch rotary shadowing, low temperature freezefracturing and conventional freeze-etching. J. Microscopie 113, 83-94.

Elkington, J.S.H. \& Fritz, I.B. (1980) Regulation of sulphoprotein synthesis by rat Sertoli cells in culture. Endocrinology 107, 970-976.

Espevik, T. \& Elgsaeter, A. (1981) In situ liquid propane jet-freezing and freeze-etching of monolayer cell cultures. J. Microscopie 123, 105-110.

Fawcett, D.W. (1975) Ultrastructure and function of the Sertoli cell. In Handbook of Physiology, Vol. 5, Section 7, chapter 2, pp. 21-55. Eds R. O. Greep \& E. B. Astwood. Am. Physiol. Soc., Washington, D.C.

Fende, P.L. \& Niewenhuis, R.J. (1977) An electron microscopic study of the effects of cadmium chloride on cryptorchid testes of the rat. Biol. Reprod. 16, 298-305.
Fritz, I.B., Rommerts, F.G., Louis, B.G. \& Dorrington, J.H. (1976) Regulation by FSH and dibutyryl cyclic AMP of the formation of androgen-binding protein in Sertoli cell-enriched cultures. J. Reprod. Fert. 46, 17-24.

Gore-Langton, R., McKeracher, H. \& Dorrington, J. (1980) An alternative method for the study of follicle-stimulating hormone effects on aromatase activity in Sertoli cell cultures. Endocrinology 107, 464-471.

Gunn, S.A. \& Gould, T.C. (1975) Vasculature of the testes and adnexa. In Handbook of Physiology, Vol. 5, Section 7, chapter 5, pp. 117-142. Eds R. O. Greep \& E. B. Astwood. Am. Physiol. Soc., Washington, D.C.

Kar, A.B. \& Das, R.P. (1960) Testicular changes in rats after treatment with cadmium chloride. Acta biol. med. germ. 5, 153-173.

Kiergzenbaum, A.L., Feldman, M., Lea, O., Austin, S. Tres, L.L., Petrusz, P. \& French, F. (1980) Localization of androgen-binding protein in proliferating Sertoli cells in culture. Proc. natn. Acad. Sci. U.S.A. 77, 5322-5326.

Lucis, O.J., Shaikh, Z.A. \& Embil, J.A. (1970) Cadmium as a trace element and cadmium binding components in human cells. Experientia 26, 11091110.

Mason, K.E., Brown, J.A., Young, J.O. \& Nesbit, R.R. (1964) Cadmium induced injury of the rat testis. Anat. Rec. 149, 135-148.

Meek, E.S. (1959) Cellular changes induced by cadmium in mouse testis and liver. Br.J. exp. Path. 40, 503-506.

Niewenhuis, R.J. \& Fende, P.J. (1978) The protective effect of selenium on cadmium-induced injury to normal and cryptorchid testes in the rat. Biol. Reprod. 19, 1-7.

Nordberg, G.F. (1971) Effects of acute and chronic cadmium exposure on the testicles of mice. Environ. Physiol. Biochem. 2, 171-187.

Parizek, J. (1957) The destructive effect of cadmium ion on testicular tissue and its prevention by zinc. $J$. Endocr. 15, 56-63.

Rommerts, F.F.G., Krüger-Sewnarain, B.C., Van Woerkom-Blik, A., Grootegoed, J.A. \& van der Molen, H.J. (1978) Secretion of proteins by Sertoli 
cell enriched cultures: effects of follicle stimulating hormone, dibutyryl cAMP and testosterone and correlation with secretion of oestradiol and androgen binding protein. Molec. cell. Endocr. 10, 39-55.

Rotman, B. \& Papermaster, B.W. (1966) Membrane properties of living mammalian cells as studies by enzymatic hydrolysis of fluorogenic esters. Proc. natn. Acad. Sci. U.S.A. 55, 134-141.

Rudd, C.J. \& Herschman, H.R. (1979) Metallothionein in a human cell line: The response of HeLa cells to cadmium and zinc. Toxicol. appl. Pharmacol. 47, 273-278.

Rugstad, H.E. \& Nordseth, T. (1975) Cadmium resistance and content of cadmium-binding protein in cultured human cells. Nature, Lond. 257, 136-137.

Saksena, S.K. \& Lau, I.F. (1979) Effects of cadmium chloride on testicular steroidogenesis and fertility of male rats. Endokrinologie 74, 6-12.
Verjans, H.L., de Jong, F.H., Cooke, B.A., van der Molen, H.J. \& Eik-Nes, K.B. (1972) Effect of oestradiol benzoate on pituitary and testis function in the normal adult male rat. Acta endocr., Copenh. 77, 636-642.

Waters, M.D., Gardner, D.E., Aranyi, C. \& Coffin, D.L. (1975) Metal toxicity for rabbit alveolar macrophages in vitro. Environ. Res. 9, 32-47.

Wunderlich, F., Wallach, D.F.H., Speth, V. \& Fisher, H. (1974) Differential effects of temperature on the nuclear and plasma membranes of lymphoid cells. A study by freeze-etch electron microscopy. Biochim. Biophys. Acta 373, 34-43.

Received 9 December 1981 